\title{
Colostral Immunoglobulins Absorption in Canchim and Nelore Calves
}

\author{
Raul Machado Netoㅁ, Irineu Umberto Packer ${ }^{2}$, Gladys Villas Boas do Prado ${ }^{3}$, Rosana Bessi ${ }^{4}$, \\ Patricia Pauletti ${ }^{5}$
}

\begin{abstract}
The efficiency of absorption of colostral immunoglobulins was evaluated in five Canchim and seven Nelore calves. They received colostrum pools with concentration of $70.20 \pm 6.14 \mathrm{mg} / \mathrm{mL}$ through esofageal feeder at 2, 12, 24 and 36 hours after birth. The immunoglobulins concentrations of the pools were estimated through specific gravity and measured by radial immunodifusion. In the blood collection at birth and during the first 70 days of life, the total protein was assayed by biuret method and the immunoglobulins were assayed by radial immunodifusion. Data were analysed as a randomized split-plot statistical model. The highest concentrations of serum immunoglobulins and total protein were observed at 24 hours of age. No significant differences $(\mathrm{P}>0.5484)$ were observed for immunoglobulins concentration at 24 hours, with concentrations of $28.80 \pm 7.24 \mathrm{mg} / \mathrm{mL}$ for Canchim and $27.32 \pm 9.54 \mathrm{mg} / \mathrm{mL}$ for Nelore. The efficiency for immunoglobulins absorption was not significantly different ( $>0.8715$ ) between breeds, $64.04 \pm 7.74 \%$ for Canchim and $62.30 \pm 6.93 \%$ for Nelore. The lack of statistical significance persisted until the fourtieth day of life, period of maternal immunoglobulin predominance in the calves blood circulation. In the following period, from 40 to 70 days of age, phase of establishment of the endogenous production of immunoglobulin, differences in the $\mathrm{IgG}$ concentrations between the two groups were detected refflecting a possible breed effect difference. The process of colostral IgG absorption by the newborn calves was not affected by breed. The differences between breeds in the calves serum $\operatorname{IgG}$ were related to the phase of endogenous production of antibodies.
\end{abstract}

Key Words: antibodies, colostrum, newborn calves, passive immunity

\section{Absorção de Imunoglobulinas do Colostro em Bezerros das Raças Canchim e Nelore}

RESUMO - A eficiência de absorção de imunoglobulinas do colostro foi avaliada em cinco bezerros da raça Canchim e sete bezerros da raça Nelore. Os bezerros receberam colostro de "pools" com concentração média de 70,20 \pm 6,14 mg/mL, por sonda esofagiana, às 2, 12, 24 e 36 horas após o nascimento. As concentrações de imunoglobulinas dos "pools" foram estimadas por gravidade específica e quantificadas por imunodifusão radial. No sangue obtido ao nascimento e durante os primeiros 70 dias de idade, a proteína total foi analisada pelo método do biureto e as imunoglobulinas séricas, quantificadas por imunodifusão radial. O delineamento experimental foi inteiramente casualizado em parcelas subdivididas no tempo. As concentrações máximas de imunoglobulinas séricas e de proteína total foram observada às 24 horas de idade. Não foi observada diferença significativa quanto à concentração de imunoglobulinas às 24 horas ( $\mathrm{P}>0,5484$ ), com valores médios de 28,80 $\pm 7,24 \mathrm{mg} / \mathrm{mL}$ para Canchim e de 27,32 $\pm 9,54 \mathrm{mg} / \mathrm{mL}$ para Nelore. A eficiência de absorção das imunoglobulinas não diferiu significativamente ( $\mathrm{P}>0,8715)$ entre as raças, sendo 64,04 $\pm 7,74 \%$ para Canchim e 62,30 $\pm 6,93 \%$ para Nelore. A ausência de diferença significativa estendeu-se até o 400 dia, período de predominância de anticorpos maternos na corrente sangüínea do bezerro. No período seguinte, dos 40 aos 70 dias de idade, fase de estabelecimento da produção endógena de anticorpos, verificaram-se diferenças na concentração de IgG entre os dois grupos de animais, refletindo provavelmente o comportamento diferenciado das raças. O processo de absorção das imunoglobulinas provenientes do colostro pelos bezerros recém-nascidos não foi afetado pela raça. As diferenças entre raças na concentração sérica de $\operatorname{IgG}$ foram relacionadas à fase endógena de produção de anticorpos.

Palavras-chave: anticorpos, bezerros recém-nascidos, colostro, imunidade passiva

\section{Introduction}

In bovines, the passive immunity transference from mother to the newborn is done through the colostrum, since the type of placenta found in these animals impairs the transport of maternal immunoglobulins to the fetus in development. The process of transference includes the concentration of maternal immunoglobulins in the mammary gland during the gestation resulting in the formation of a

\footnotetext{
${ }^{1}$ Eng. Agrôn., Prof. Titular, Depto. de Zootecnia, ESALQ-USP, Caixa Postal 9, CEP: 13418-900, Piracicaba, SP. E-mail: rmachado@esalq.usp.br 2 Eng. Agrôn., Prof. Titular, Depto. de Zootecnia, ESALQ-USP, Caixa Postal 9, CEP: 13418-900, Piracicaba, SP. E-mail: iupacker@carpa.ciagri.usp.br

3 Eng. Agrôn., Depto. de Zootecnia, ESALQ-USP, Caixa Postal 9, CEP: 13418-900, Piracicaba, SP.

${ }^{4}$ Eng. Agrôn., PhD., Depto. de Zootecnia, ESALQ-USP, Caixa Postal 9, CEP: 13418-900, Piracicaba, SP. E-mail: piracicaba@btconnect.com

${ }^{5}$ Eng. Agrôn., PhD., Depto. de Zootecnia, ESALQ-USP, Caixa Postal 9, CEP: 13418-900 Piracicaba, SP. E-mail: ppaulett@bol.com.br
} 
very special secretion, colostrum, and a temporary permeability of the newborn intestinal cells, allowing absorption of intact immunoglobulins (Larson \& Kendall, 1957; Brambell, 1958).

In the newborn calf, the passive immunity obtained from colostrum reaches the maximum blood serum concentration at the first 48 hours of life. Thereafter, the concentration of serum immunoglobulins declines in consequence of the catabolism and transference of the antibodies to different metabolic pools. The establishiment of endogenous production of IgG increases its concentration until normal levels are reached (Tennant et al., 1969; Bush et al., 1971; Husband et al., 1972; Ribeiro et al., 1983; Machado Neto \& Packer, 1986; Baracat et al., 1997).

The concentration of serum $\operatorname{IgG}$ in the first 48 hours of life does not reflect the efficiency of absorption during the period of intestinal permeability. The apparent efficiency of absorption (AEA) of immunoglobulins is calculated considering the serum IgG concentration, plasma volume and the amount of IgG consumed by the newborn. Several studies indicates that among innumerous factors that can influenced serum protein absorption the most importants are quality and time of the first consumption of colostrum (Comline et al., 1951; Kruse, 1970; Bush et al., 1973; Besser et al., 1985; Quigley et al., 1998; Klobasa et al, 1998). Vann et al. (1995), studying the process of colostral antibodies absorption in calves, found an efficiency of $26 \%$ for $\mathrm{IgG}, 62 \%$ for $\operatorname{IgM}$ and $19 \%$ for $\operatorname{IgA}$, in the first 6 hours of life. Husband et al. (1972), Boyd \& Boyd (1987) and Klobasa et al. (1998) observed values between 42 and $46 \%$ for immunoglobulin $\mathrm{G}$, when colostrum was consumed between two and seven hours post-partum. Higher values of absorption efficiency were found by Bush et al. (1973) e Matte et al. (1982), 66\% and 65,8\%, respectively.

The purpose of the present study was to evaluate the efficiency of immunoglobulin $\mathrm{G}$ absorption and the following serum fluctuation of it in Canchim and Nelore calves.

\section{Materials and Methods}

Seven calves of Nelore breed and five of Canchim breed were separated from their mother, without the opportunity of ingesting any maternal colostrum, and received colostrum from pools previously prepared, with average concentration of immunoglobulins of
$70.20 \pm 6.14 \mathrm{mg} / \mathrm{mL}$. Four meals equivalent to a $5 \%$ of live weight each, were offered at 2, 12, 24 and 36 hours after birth. Before the storage at $-20^{\circ} \mathrm{C}$, the $\mathrm{IgG}$ concentration of the pools were quantified and adjusted. Blood samples from jugular vein were collected at birth, 12, 24, 36 and 48 hours post-partum, and 5, 10, 15, 17, 20, 25, 30, 40, 50, 60 and 70 days of life.

The apparent efficiency of absorption (AEA) was determined using the formula established by Husband et al. (1973) and modified by Besser \& Osborn (1993).

[Serum IgG x Plasmatic volume]

$$
\text { AEA }(\%)=\frac{}{\text { Colostral IgG Concentration x }} \text { X } 100
$$

For the plasmatic volume was used the value $8,9 \%$ in relation to live weight, value found by Besser \& Osborn (1993), using the method Evan Blue dye with blood samples collected from calves at 12 hours of life.

The concentration of serum immunoglobulins was determined by radial immunodifusion (Mancini et al., 1965). The concentration of immunoglobulins in the pools of colostrum was also determined by radial immunodifusion according to Mancini et al., 1965, modified by Fleenor \& Stott (1981). The total protein was quantified by biuret method (Reinhold, 1953). Data were analysed as a randomized split-plot statistical model through the PROC GLM SAS (1999) procedure.

\section{Results and Discussion}

The average concentration of serum total protein (TP) and serum IgG are shown in Figure 1 and Figure 2.

The peak of TP concentration obtained at 24 hours of life differed significantly between the breeds $(\mathrm{P}<0.0105)$, with values of $7.01 \pm 0.72 \mathrm{~g} / 100 \mathrm{~mL}$ for Nelore and $7.91 \pm 0.37 \mathrm{~g} / 100 \mathrm{~mL}$ for Canchim. A peak at 24 hours was also found for $\operatorname{IgG}$ with no statistical differences between breeds $(\mathrm{P}<0.5458)$, with values of $27.32 \pm 9.54 \mathrm{mg} / \mathrm{mL}$ for Nelore and $28.80 \pm 7.24 \mathrm{mg} / \mathrm{mL}$ for Canchim.

These results indicate that the differences found between breeds related to TP at 24 hours are not dependent of $\mathrm{IgG}$ portion. This fact could be justified by the maternal origin of IgG in this early phase of life of the newborn calf, obtained from colostrum which

R. Bras. Zootec., v.33, n.6, p.1544-1547, 2004 


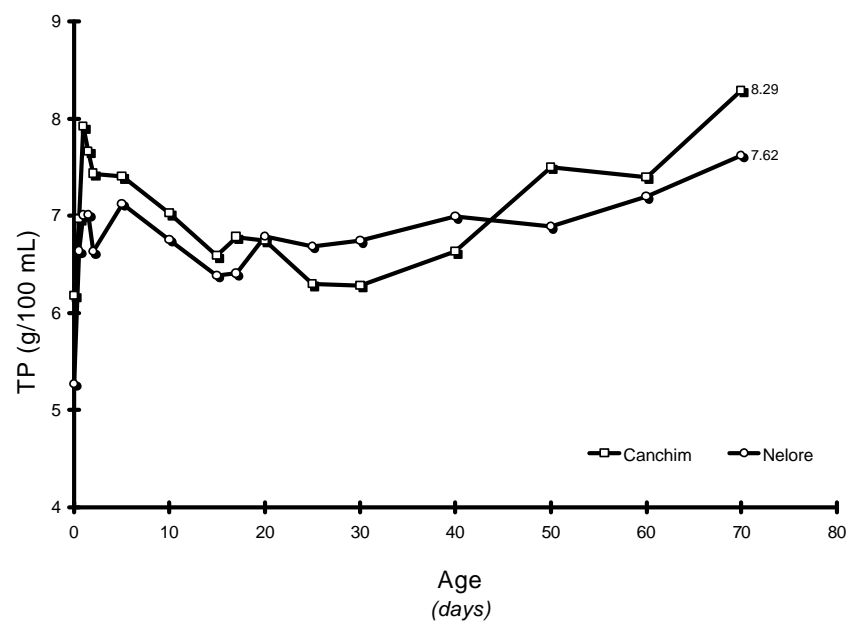

Figure 1 - Serum total protein (TP) $(\mathrm{g} / 100 \mathrm{~mL})$ in Canchim and Nelore calves.

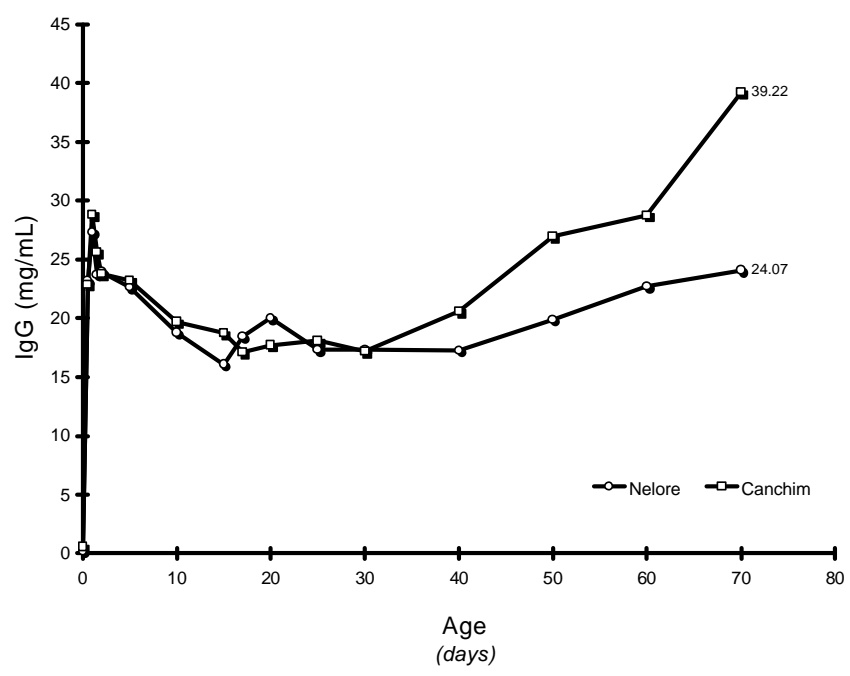

Figure 2 - Serum IgG concentration $(\mathrm{mg} / \mathrm{mL})$ in Canchim and Nelore calves.

was provided in uniform quantity and concentration and at a specifc time. These procedures indicate that the differences found in TP are related to other proteins different than IgG.
Serum TP and IgG were significantly correlated $(\mathrm{P}<0.0001)$ considering the entire experimental period $(\mathrm{r}=0.607)$. The correlation between $\mathrm{TP}$ and $\mathrm{IgG}$ $(\mathrm{r}=0.732)$ in the first 24 hours of life was also positive $(\mathrm{P}<0.0068)$. Several authors also verified a positive correlation between TP and IgG in calves during the initial period of life (Machado Neto \& Packer, 1986; Daniele et al., 1994; Nocek et al., 1984; Baracat et al., 1995; Pauletti et al., 2002).

The calculated minimum average concentration of serum $\mathrm{IgG}$ was $10.12 \pm 2.22 \mathrm{mg} / \mathrm{mL}$ for Nelore and $13.96 \pm 1.33 \mathrm{mg} / \mathrm{mL}$ for Canchim, without significant difference $(\mathrm{P}<0.2314)$. The dates of ocurrence of the minimun serum concentration of $\mathrm{IgG}, 29.25 \pm 4.71$ days for Canchim and $31.17 \pm 8.77$ days for Nelore, were also not significantly different $(\mathrm{P}<0.8727)$.

The efficiency of absorption of IgG at 12 hours of age was $64.04 \pm 7.74 \%$ for Canchim and $62.30 \pm$ $6.93 \%$ for Nelore, without significant difference $(\mathrm{P}<0.8715)$. These results agree with those obtained by Bush et al. (1973) and Matte et al. (1982).

The results obtained for the absorption efficiency, as well the general pattern of serum antibodies are comparable to the values obtained for dairy calves in other studies (Husband et al., 1972; Bush et al., 1973; Matte et al., 1982; Machado Neto \& Packer, 1986, Pauletti et al., 2002).

The curve of IgG fluctuation was divided in two periods: the exogenous period, from birth to the minimun point, corresponding to the phase of predominance of circulating antibodies acquired from maternal colostrum, and endogenous period starting at around 40 days of life, when the of $\mathrm{IgG}$ concentration starts to reflect the calf own synthesis. From this point on, it was possible to verify differences in IgG concentration between Nelore and Canchim, condition that can be detected in the dates 40 days $(\mathrm{P}<0.1237), 50$ days $(\mathrm{P}<0.0918), 60$ days $(\mathrm{P}<0.2642)$ and 70 days $(\mathrm{P}<0.0842)$, (Figure 2$)$.

\section{Conclusions}

The process of colostral IgG absorption by the newborn calves was not affected by breed.

The differences between breeds in the calves serum $\mathrm{IgG}$ were related to the phase of endogenous production of antibodies. 


\section{Literature Cited}

BARACAT, R.S.; MACHADO NETO, R.; DANIELE, C. et al. Influência do fornecimento prolongado de colostro sobre a flutuação de proteínas séricas em bezerros com diferentes níveis de imunidade passiva sérica. Scientia Agricola, v.52, n.3, p.537-542, 1995.

BARACAT, R.S.; MACHADO NETO, R.; DANIELE, C. et al. Fornecimento prolongado de colostro e proteção passiva em bezerros recém-nascidos. Pesquisa Agropecuária Brasileira, v.32, n.11, p.215-1220, 1997.

BESSER, T.E.; GARMEDIA, A.E.; MCGUIRE, T.C. et al. Effect of colostral immunoglobulin- $\mathrm{G}_{1}$ and immunoglobulin-M concentrations on immunoglobulin absorption in calves. Journal of Dairy Science, v.68, n.8, p.2033-2037, 1985.

BESSER, T.E.; OSBORN, D. Effect of bovine serum-albumin on passive transfer of immunoglobulin- $\mathrm{G}_{1}$ to newborn calves. Veterinary Immunology and Immunopathology, v.37, n.3-4, p.321-327, 1993.

BOYD, J.W.; BOYD, A.J. Computer-model of the absorption and distribution of colostral immunoglobulins in the newborn calf. Research in Veterinary Science, v.43, n.3, p.291-296, 1987.

BRAMBELL, F.W.R. The passive immunity of the young mammal. Biological Reviews, v.33, n.4, p.488-531, 1958.

BUSH, L.J.; AGUILERA, M.A.; ADAMS, G.D. Absorption of colostral immunoglobulins by newborn dairy calves. Journal of Dairy Science, v.54, n.10, p.1547-1549, 1971.

BUSH, L.J.; MUNGLE, M.B.; CORLEY, L.D. et al. Factors affecting absorption of immunoglobulins by newborn dairy calves. Journal of Dairy Science, v.56, n.2, p.312-312, 1973.

COMLINE, R.S.; ROBERTS, H.E.; TITCHEN, D.A. Route of absorption of colostrum globulin in the newborn animal. Nature, v.167, p.561-562, 1951.

DANIELE, C.; MACHADO NETO, R.; BARACAT, R.S. et al. Efeito de diferentes manejos no fornecimento prolongado de colostro sobre o comportamento imunológico e desempenho de bezerros leiteiros recém-nascidos. Revista da Sociedade Brasileira de Zootecnia, v.23, n.2, p.211-222, 1994.

FLEENOR, W.A.; STOTT, G.H. Single radial immunodiffusion analysis for quantitation of colostral immunoglobulin concentration. Journal of Dairy Science, v.64, n.5, p.740-747, 1981.

HUSBAND, A.J.; BRANDON, M.R.; LASCELLES, A.K. Absorption and endogenous production of immunoglobulins in calves. Australian Journal of Experimental Biology and Medical Science, v.50, n.4, p.491-498, 1972.

HUSBAND, A.J.; BRANDON, W.R.; LASCELLES, A.K. The effect of corticosteroid on absorption and endogenous production of immunoglobulins in calves. Australian Journal of Experimental Biology and Medical Science, v.51, p.707-710, 1973.

KLOBASA, F.; GOEL, M.C.; WERHAHN, E. Comparison of freezing and lyophilizing for preservation of colostrum. Journal of Animal Science, v.76, n.4, p.923-926, 1998.
KRUSE, V. Absorption of immunoglobulin from colostrum in newborn calves. Animal Production, v.12, n.4, p.627-638, 1970 .

LARSON, B.L.; KENDALL, K.A. Changes in specific blood serum protein levels associated with parturition in the bovine. Journal of Dairy Science, v.40, p.659-666, 1957.

MACHADO NETO, R.; PACKER, I.U. Flutuação de imunoglobulina sérica em bezerros da raça Holandesa submetidos a diferentes regimes de aleitamento. Revista da Sociedade Brasileira de Zootecnia, v.15, n.5, p.439-447, 1986.

MANCINI, G.; CARBONARA, A.O.; HERMANS, J.F. Immunochemical quantitation of antigens by single radial immunodiffusion. Immunochemistry, v.2, n.3, p.253-254, 1965

MATTE, J.J.; GIRARD, C.L.; SEOANE, J.R. et al. Absorption of colostral immunoglobulins $\mathrm{G}$ in the newborn dairy calf. Journal of Dairy Science, v.65, n.9, p.235-254, 1982.

NOCEK, J.E.; BRAUND, D.G.; WARNER, R.G. Influence of neonatal colostrum administration, immunoglobulin, and continued feeding of colostrum on calf gain, health and serum protein. Journal of Dairy Science, v.67, n.2, p.319-333, 1984.

PAULETTI, P.; MACHADO NETO, R.; PACKER, I.U. et al. Efeito de diferentes níveis iniciais de imunoglobulinas adquiridas do colostro sobre a flutuação de proteínas séricas e desempenho de bezerras da raça Holandesa. Pesquisa Agropecuária Brasileira, v.37, n.1, p.89-94, 2002.

QUIGLEY, J.D.III; FIKE, D.L.; EGUTON, M.N. et al. Effects of a colostrum replacement product derived from serum on immunoglobulin $\mathrm{G}$ absorption by calves. Journal of Dairy Science, v.81, n.7, p.1936-1939, 1998.

REINHOLD, J.G. Total protein, albumin and globulin. In: REINER, M. (Ed.) Standard methods of clinical chemistry. New York: Academic Press, 1953. v.1, p.88.

RIBEIRO, M.F.B.; BELEM, P.A.D.; PATARROYO, J.H.S. et al. Hipogamaglobulinemia em bezerros. Arquivo Brasileiro de Medicina Veterinária e Zootecnia, v.35, n.4, p.537546, 1983.

STATISTICAL ANALYSES SYSTEM - SAS. SAS On Line Doc ®. Version 8. Cary: 1999.

TENNANT, D.V.M.; HARROLD, D.B.S.; REINA-GUERRA, M.B.S. et al. Neonatal alterations in serum gamma globulin levels of Jersey and Holstein-Friesian calves. American Journal of Veterinary Research, v.30, n.3, p.345-354, 1969.

VANN, R.C.; HOLLOWAY, J.W.; CARSTENS, G.E. et al. Influence of calf genotype on colostral immunoglobulins in Bos-taurus and Bos-indicus cows and serum immunoglobulins in their calves. Journal of Animal Science, v.73, n.10, p.3044-3050, 1995. 